ite in the hydrogen clays at the end of the above cycle of operations. A relation between the mineralogical composition of the clay and the quantities of displaced $\mathrm{Al}^{++}+$and $\mathrm{Fe}_{\Theta}++$ ions is indicated by the above results. Further work with pure clay minerals is in progress.

These investigations have been carried out with the aid of a grant from the Imperial Council of Agricultural Research, India.

Physical Chemistry and

J. N. MUKHERJEE.

B. ChatTerjee.

Colloid Research Laboratories,

University College of Science and Technology, 92 Upper Circular Road, Calcutta.

1 Page, Verti, 2 Komm. Int. Bodenk., 232 (1926).

2 Magistad, Soil Sci., 20, 181 (1925).

selly and Brown, Soil. Sci., 21, 289 (1926).

- Wilson, Soil Sci., 28, 411 (1929).

${ }^{5}$ Mattson, Soil Sci., 25, 345 (1928)

- Daikuhara, Bull. Imp. Cent. Agr. Expt. Sta. Japan, 2, 18 (1914).

${ }^{7}$ Kappen, Landw. Versuchstat., 88, 96 (1916).

- Paver and Marshall, J. Soc. Chem. Indust., 53, 750 (1934).

- Chatterjee, Bull. Ind. Soc. Soil. Sci., No. 4, 148 (1942).

${ }^{10}$ Mukherjee and Chatterjee, Ind. J. Agric. Sci., 12, 105 (1942).

${ }^{11}$ Chatterjee and Paul, Ind. J. Agric. Sci., 12, 113 (1942).

${ }^{12}$ Mukherjee, Chatterjee and Goswami, J. Ind. Chem. Soc., 19, 405 (1942).

${ }^{13}$ Chatterjee and Majumdar, unpublished results.

14 Truog, Pearson, Weeks and Simonson, Proc. Soil. Sci. Soc., Amer., 1, 101 (1936).

15 Bagchi, unpublished results.

${ }^{16}$ Mitra, Indra and Roy, Proc. Ind. Sci. Congress Assoc., 3, 152 (1944).

${ }^{17}$ Mukherjee, Mitra and Mitra, J. Phys. Chem., 47, 543 (1943).

${ }^{18}$ Mitra, Bagchi and Roy, J. Phys. Chem., 47, 549 (1943).

${ }^{10}$ Unpublished work of Dr. B. Chatterjee and B. N. Banerjee.

\title{
Structure of Aluminium Trimethyl
}

THE existence of the dimer aluminium trimethyl has aroused considerable interest. Electron diffraction determinations ${ }^{1,2}$ are in satisfactory agreement with an ethane structure (I). However, this structure is for many reasons most unlikely: (1) it should differ from the bridge structures of the related aluminium halides ${ }^{3} \quad \mathrm{Al}_{2} X_{6}$, aluminium dimethylhalides ${ }^{2} \mathrm{Al}_{2} \mathrm{Me}_{4} X_{2}$, as well as of the boron and probably aluminium hydrides ${ }^{4} ;$ (2) it cannot be accounted for by any existing valence theory; no forces are available for joining the two AlM $_{3}$ molecules; (3) it requires a shorter interatomic distance (about $2 \cdot 20 \mathrm{~A}$.) between the equally charged Al atoms than that of a covalent Al-Al linkage ( $>2.48$ A.) ; (4) the unstability (non-existence) of a dimer boron trimethyl cannot be explained.

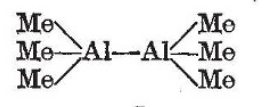<smiles>C[Ge]1(C)C[Ge](C)(C)C1</smiles>

II<smiles></smiles>

IV
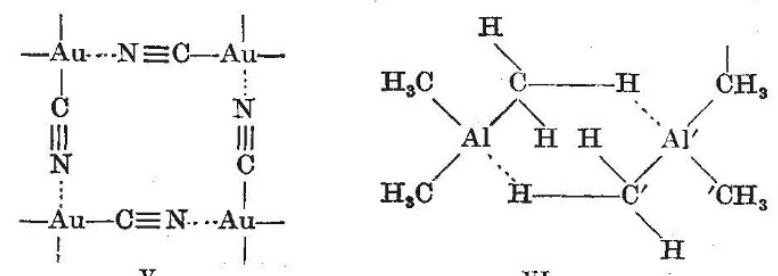

Raman spectra favour a bridge structure ${ }^{5}$, but that of type II is excluded by the results of electron diffraction determinations ${ }^{2}$. As shown elsewhere ${ }^{6}$, the stability of $\mathrm{B}_{2} \mathrm{H}_{6}$ and $\mathrm{Al}_{2} \mathrm{H}_{6}$ can be accounted for on the basis of the bridge structure ${ }^{4}$ by the formation of $\mathrm{B}$... H hydrogen bonds (of an essentially electrostatic nature) (III). This also allows a bridge structure for $\mathrm{Al}_{2} \mathrm{Me}_{6}$, which has not yet been considered (VI). A six-membered ring is formed by Al ... H hydrogen bonds. Owing to the inductive electron transfer from the positive Al atom, the negative charge on the $\mathrm{H}$ atom should be appreciable. The non-existence of $\mathrm{B}_{2} \mathrm{Me}_{6}$ can be explained by the much smaller electron transfer from the lesspositive $B$ atom, which is not compensated by the expected shorter interatomic distance. $\mathrm{Al}_{2} \mathrm{Me}_{6}$ is now no exception to the bridge structures of its related aluminium and boron derivatives. This is comparable to the dimer gold dialkyl halides and tetramer cyanides? ${ }^{7}$ where one atom (halogen) (IV) and two atoms $(\mathrm{C} \equiv \mathrm{N})$ (V) respectively form the bridge. No new valence theory is required, and the $\mathrm{Al}-\mathrm{Al}$ distance is now longer than that of a covalent linkage.

It is noteworthy that the distances to be expected for structure VI are in qualitative agreement with the peaks of radial distribution curves derived from electron diffraction determinations, which are $2 \cdot 07$, $2 \cdot 6,3 \cdot 42,3 \cdot 93^{1}$ and $2 \cdot 01,2 \cdot 58,3 \cdot 3,4 \cdot 05 \mathrm{~A}$. respectively ${ }^{2}$. The C-H and Al-C distances within the six-membered ring will be near 1.09 and $2.01 \mathrm{~A}$. respectively, the Al . . H distance slightly longer than that of a covalent linkage and not very different from $(1 \cdot 7) 1 \cdot 8 \mathrm{~A}$. Making the reasonable assumption that the angles CAlH and AlCH in the ring are about $109 \cdot 5^{\circ}$, the important distances mainly contributing to the radial distribution curve below $4 \mathrm{~A}$. are $\mathrm{Al}-\mathrm{C}$ $2 \cdot 01$ A., Al-C' $2 \cdot 73$ A., Al-H 2.59 A., Al-Al' 3.22 A., C $-\mathrm{C} 3 \cdot 28$ A., $\mathrm{C}-\mathrm{C}^{\prime}$ (both in ring) $3 \cdot 5 \mathrm{~A}$., C (in ring) $-\mathrm{C}^{\prime}$ (outside ring) $4.0 \mathrm{~A}$. These distances show a reasonable relationship to the observed peaks. This should justify new quantitative calculations, based on the suggested bridge structure, for testing such models and possibly establishing its actual dimensions.

College of Technology,

A. Burawoy.

Manchester, 1. Dec. 14

${ }^{1}$ Davidson, Hugill, Skinner and Sutton, Trans. Far. Soc., 36, 1212 (1940).

"Broackway and Davidson, J. Amer. Chem. Soc., 63, 3287 (1941).

? Palmer and Elliot, J. Amer. Chem. Soc., 60, 1852 (1938).

- Longuet-Higgins and Bell, J. Chem. Soc., 250 (1943).

${ }^{5}$ Kohlrausch and Wagner, Z. phys. Chem., B, 62, 153 (1942) (from Brit. Chem. Abstr., A I, 50 (1943)).

- Burawoy, Nature, in the press.

7 Burawoy, Gibson and others, J. Chem. Soc., 860 (1934); 217, 219, 1024 (1935); 1690 (1937): cf. also Phillips and Powell, Proc. Roy. Soc., A, 173. 147 (1939).

\section{Mechanism of the Red Cell Changes in Non-hæmolytic Jaundice}

Certain characteristic changes are found in the erythrocytes in obstructive jaundice. The red cells are increased in diameter but not in thickness, so that they are relatively flat cells. Associated with this alteration in shape, target cells are seen in the blood in large numbers and the red cells are resistant to hæmolysis by hypotonic saline solutions. The volume of the cells may or may not be increased.

The same changes have been demonstrated in cases of toxic-infective jaundice. Here, in most 